\title{
NUTRITIONAL DISORDER IN CHILDREN
}

\section{Dr. Rajesh Prabhakar Bholane}

Professor, Dept of kaumabritya , siddhakala ayrveda Mahavidyalya TQ. Sangamner, Dist: Ahmednagar

\section{ABSTRACT}

Nutrition is the basic necessity of mankind and diseases resulting from its inadequacy or more use have existed even before the dawn of modern science Ayurveda which is the ancient system of Indean medicine has described these diseases with their etiology \& treatment. This article reviews the ancient wisdom of nutritional disorders in children \& critically analysis it in light of contemporary science and evidences. The treatment described in classics is relevant with a scope of clinical and laboratory research on them.The materials were collected from thePediatric textbooks,Magazines, classical Ayurveda literatures\& Research journals.

Keywords - Nutritional disorders in Ayurveda Karshya, Balshosha, Phakka, Parigarbhika 


\section{INTRODUCTION}

In the worldlndia is one of the highest ranking countries for no. of children suffering from malnutrition. Nutritional disorders comprise of both undernutrition \& over nutrition.

Undernutrition is a condition in which there is excessive loss of nutrients inadequate consumption, poor absorption of nutrients.

Childhood malnutrition is an underlying cause in an estimated $35 \%$ of all deaths among children under 5 \& $21 \%$ of total global disability adjusted life year lost among under 5 children.

According to National family Health Survey (NFHS) Carried out in 2005-06--$40 \%$ of India's Children under age of

1)3 - Underweight (Low height for age)

$45 \%$ - Stuned (Low weight for height)

$23 \%$ - wasted (Low weight for height)

2)Aahara is one of three sub pillars of life as per Ayurveda. The transforming unit from food into nutrition is termed as "Agni."

\section{Malnutrition Description in Ayurveda}

1) Karshya

4) Karshya is under nutrition condition Caused due to reduced food intake of baby. if mother use vatavardhak Aaharavihara \& baby take vatadushit stanya ultimately baby become malnourished.

Samprapti- Nidan sevana (vatavardhaka Aahara vihara)

$\rightarrow$ Vitiation of vata $\rightarrow$ Angi Dushti $\rightarrow$ Formatioin of Ama $\rightarrow$ Dhatukshya $\rightarrow$ Inadequate Rasa Dhatus $\rightarrow$ under Nourish Rasadhatu circulate in whole body $\rightarrow$ Alpaposhan of Dhatu $\rightarrow$ Karshya.
Chikitsa-

Light and nourishing diet prescribed for nourishment of karshya

patient like old shali,Regular oil massage, Administration of brimhana Drugs.

2) Balshosha ${ }^{6}$ Acharya vagbhata discribed this disease of children .

\section{Samprapti -}

Intake of chilled water \& Breast milk vitiated by kapha cause an imbalance in doshas \& kapha rises in baby $\rightarrow$ kapha causes obstruction in Rasavaha strotas of child which are channels for nutrition, thus causing undernutition.

\section{Lakshana-}

Lack of appetite

Recurrentrespiratory infection

Cough, fever

Paleness of face \& eyes

$>$ Chikitsa-

8)Forcontrol Balshosha $\rightarrow$ snehapana, use of anabolic herbs \& preparation along appetizers is recommended. efforts are made to clear obstructed channels \& to purify vitiated milk in mother.

3) Paarigarbbikam

8)Described by A.S which states that, whenpregnant mother breastfeeds the baby or there is an abrupt stoppage of breast milk to baby due to pregnancy of mother, baby suffers from 'Paarigarbhika.' 
> Symptoms- loss of appetitecough, cold, impaired digestive capacity, vomiting, fever.

$>$ Chikitsa-

8) Ideal treatment is Agnideepana chikitsa

Treatment should be aimed tobring Agni to narmaly (correct of digestion \& appetite)

Highly brimhana diet (High calorie \& protein).

\section{अत्युद्रिक्तंक्षुधंबालंपरिभुतंतुलेहयेत|}

\section{विदरियवगोधुमकणाचूर्ण घृताप्लुतं।}

पायायेदनुचक्षीरशृतं समधुशर्करम् ॥| A.S.U 2/43

4) Phakka

The word phak Means slow movements or creeping like snail / failure of skill of locomotion even after age of 1 year. So when child becomes crippled with wasting of body and slow movements he is said to be suffering from phakka

- 7)Acharya kashyappa described 3 types of phakka

1) Ksheeraja-

\section{बालः सवस्त्सरापादाभ्यांयोनगच्छति|}

\section{सफक्क इतिविजेय: ।}

kapha vitiated breast milk known as phakkadugdha

2) Garbhaja-

\section{धात्रीश्लैश्मिकदुगद्धातु फक्कदुग्धेनिसंजित ।}

तत्तिर्षरपोबहुत्याधि: काश्ड़्यातफक्कात्वमपनुयात्।।
When mother whose baby is still On breast feeding conceive again which result in decrease quantity and quality of mother's milk

3) Vyadhij

निजैरज्तृभिश्चैव. ज्वरदिभि:।

Caused by chronic illness and unhygienic conditions

Clinical Feature -

Waisting of buttocks, thighs and upper limbs, pot belly, inability to walk

Chikitsa-

\section{वस्तय: स्नेहापानानि स्वेदाश्चोद्वर्तनानि च ।}

\section{वातरोगेषुबालानांसंसृष्टेषु विशेषत:।।}

Depends on cause

1) Milk impurity $\rightarrow$ Treatment to mother

Snehan withkalyanaka ghrita followed by shodhan .

Administration of drugs having property of activating neuromuscular rresponseRasna, punarnava, along with samvardhana ghrita.

Abhyanga with Raj taila advised to improve muscle tone.

- $\quad$ Using phakkaratham

\section{त्रिचक्रंफक्करधकंप्राश:शिल्पिकनिर्मितं।}

\section{विददयाऽतेशनकैगृहीतो गतिमभ्यारोत्।}

Conclusion :-

1) Malnutrition is described in modern medical sciences but similar to kuposhanjanyavyadhi in Ayurveda like karshya, Bashesha, Parigarbhika, phakka

2) Nutrition deficiency inflicts long term damage to both baby and society 
Undernourished children are more prone to infections like pneumonia and TB which leads to higher mortality rate

3) A systemic study of these conditions provide in sight to hazards of nutritional deficiencies and proper understanding of pathogenesis of conditions provide valuable key for effective management.

\section{References}

1) O.P.Ghai essential pediatrics seventh edition CBS publishers and distributors pvt Ltd nutrition 2012:62

2) Bramhanand and Tripathi charaka samhita - purvardha

Sutrasthana Tristraishaniya 1 1/35

Chaukhambiya prakashan edition 2010

3) Bramhanand and Tripathi charaka samhita - purvardha

Sutrasthana Ashtauninditiya 21/3,1 1, 12,15
Chaukhambiya prakashan edition 2010

4) Ambika Duttashastri suspect samhita Purvardha

Dosh Dhatu Mala Kshaya Ruddhividnyaniya 15/33

Chaukhambiya prakashan edition 2014

5) Bramhanand Tripathi charak samhita Purvardha

Ashtauninditiya 21, Chaukhamba prakashan 2010

6) Murthy K.R srikantha edited vagbhatta's Ashtanga Hridayam Vol.3 Chaukhamba Publications 2021 Ch 21/44-56

7) Tiwari $P \vee$ kasypa samhita edition 1996 varanasi Chaukhamba Publications chikibasthan phakkaroga

8) Vriddhavagbhat Ashtanga Sangraha Chaukhamba Publications utyar tantra 2/64,3/21. 